\title{
Are political support-driven policies always bad? The case of large interest groups
}

Gael Lagadec, University of New Caledonia

\begin{abstract}
The action of active interest groups (lobbies) has been traditionally considered to be a source of harmful waste for the economy which reduces social well-being. Can this analysis be adapted to the case of large unorganised groups which do not ask for anything directly? Or, on the contrary, does the setting up of policies which improve the situation of these large groups permit an improvement in social welfare? We start from classical (public choice) analyses of lobbying and rentseeking developed since the 1970s, closely linked with the hypothesis of reelection-seeking politicians, before extending our analysis also to consider nonsector-specific policies and passive interest groups (notably those too large to meet the Olsonian condition of efficient collective action). Then the research question to be answered becomes whether promoting the interest of large groups can deliver social welfare as defined by the incumbent's social welfare function. We refer to the political cycles' evidence to consider that no social welfare objective can motivate the favouring of large groups.
\end{abstract}

\section{JEL classification}

D71; D72.

\section{Keywords}

Interest groups; lobbies; collective action; social welfare.

\section{Acknowledgements}

Financial support from the Fonds Pacifique of the French Overseas Ministry is gratefully acknowledged. The usual disclaimer applies. 


\section{Introduction}

Free trade is generally considered to be the optimal policy for a small open economy. If free trade is associated with lump sum transfers between individuals, it is then in the interest of each individual in an economy (e.g. Hillman 1989: 1), and is a Pareto optimum at the international level. Nevertheless it has traditionally been recognised that a few exceptions to this rule exist (e.g. protection of emerging industries, optimal tariff), but for which the practical application can appear very limited (e.g. Magee, 1997: 532). If social welfare is maximised for zero protection, positive protection is suboptimal. How can this situation be explained, as in reality international exchanges are hindered by numerous barriers, and no State practices free trade? (Magee, 1997: 542) Why would a country choose a suboptimal situation for itself rather than an optimal solution? Firstly, the case of a suboptimal situation in which each of the agents finds themselves in a situation inferior to that of the optimal situation, must be excluded. In fact, whichever way economic and trade policy are formed, they come from at least one individual, if not from a majority. An effective suboptimal policy thus advantages certain agents and disadvantages others. This policy is thus implemented by the agents who benefit from it. The idea of a benevolent government must therefore be dismissed; as social welfare is not the criterion which guides the policy (otherwise free trade would prevail). A protectionist trade policy, whatever the degree, is therefore shaped by private interests. Thus protectionism must be the result of a political process. ${ }^{1}$ Trade policy is the privileged instrument of political support; the other instruments at the disposal of government have the disadvantage of being too transparent (Grossman and Helpman, 1995: 680). However there is no reason to think that trade policy is the only lever of political support.

In this article the concept of endogenous policy is extended to economic policy in the widest sense. In this context the effects on welfare of policies implemented by re-election seeking politicians, or more simply those looking for political support, will be discussed to answer this question: in the case of interest groups driven political support would the traditional negative link between lobbying and welfare be reversed?

In the first section the principle of lobbying will be summarised and the concept of political support will be extended to unorganised interest groups. In the second section the commonly acknowledged effects of lobbying on social welfare will be presented and the link between the satisfaction of unorganised interest groups and social welfare will be emphasised. The last section shows the empirical relevance of our approach.

\section{Lobbies and interest groups: a new look at endogenous policies}

\section{Small versus large groups}

For private interests to shape economic policy, it has been traditionally considered that they need to organise themselves into pressure groups (lobbies). Apart from the pressure itself, the activity of the lobby is rent-seeking, which corresponds to obtaining a (beneficial) non-competitive situation. In the case of trade policy, tariffs are endogenous when they are established in response to the demands of lobbies,

\footnotetext{
${ }^{1}$ This has been acknowledged for a long time; see Baldwin (1984: 674), Grossman and Helpman (1994: 835), Hillman (1992: 7), Mayer (1984: 983), Peirce (1991: 276), Pincus (1975: 763), Wellisz and Wilson (1986: 369).
} 
and we can then talk about endogenous protection ${ }^{2}$ (for empirical evidence of the endogenous aspect of protection see Hillman, 1989: 133-149).

A distinction must be made between pressure groups (lobbies) and interest groups. A lobby is primarily an interest group but, unlike the latter, the members of the group have joined forces to organise a collective action in order to collectively pursue their individual common interest.

In fact, according to Baldwin (1982) there are a certain number of basic factors for a lobby to appear (necessary conditions, especially including Olsonian conditions ${ }^{3}$ related to small-size groups) but, according to him, a triggering factor is necessary to initiate the change from potential lobby (that is the interest group) into active lobby (pressure group). This "trigger" could be a crisis, or a series of crises striking the common interests of the members of the potential lobby (Baldwin, 1982: 279). This means that the individuals organise themselves more naturally or more efficiently to counter losses than to seek income (realistic hypothesis that an individual perceives a loss more acutely than the loss of potential gain). Once the lobby is set up, it can become more efficient and organise itself, not only against losses or risks of losses, but also to obtain advantages (which particularly lead to theories of "rent seeking"). Conversely, interest groups have not overcome the obstacles related to collective action, which is most often due to their characteristic of large size. In the literature on political support it is generally considered that everything that is endogenous comes from lobbies.

An original feature of this paper is to consider taking the interests of large groups into account on the grounds of political support, which thus establishes endogenous policies which are not sector-based ("global policies"). If this idea is not widespread it is nevertheless not new, and it seems that this demarcation criterion between endogenous sector-based or global policies could be credited to an article by Travis (1968).

In this way Travis showed that American tariffs specific to labour protection were prohibitive whatever the sector concerned (Travis, 1968: 640). This study meant that if one considered a large unorganised group obtaining protection, the protection could be explained other than in terms of lobbying. The large group could in fact be protected by the government because it represents significant electoral weight. As Browning (1974: 376) then pointed out the government can elaborate legislation to win votes, even without lobbying. One may think considering political support in terms of number of ballots would make political support and social welfare converge (the political process being a way to aggregate individual preferences, despite its weaknesses known since Condorcet's paradox).

However, legislation made to win votes from an identified population group is the expression of an "endogenous" policy in that it is not driven by the search for social welfare (which comes back to the fact that social welfare is not an addition of individual well-being or of community interest in a Benthamian way).

\footnotetext{
2 The counterpart of the protection is either promises of financial contributions given to political candidates by the lobbies before the election (a typical approach to electoral competition, pioneered by Brock and Magee, 1978) or recurring financial contributions given to the incumbent by the lobbies to fine tune the shape of protection they benefit (a typical approach to "influence driven contributions" pioneered by Peltzman, 1976, and formalised by Helpman and Grossman, 1994, 1995).

3 The cases in which collective action could emerge are the cases where at least certain production factors are not mobile ("specific" production factors). These specific production factors form the common interest of the different producers of the same product. However the existence of specific production factors is not a sufficient condition for the formation of lobbies (Grossman and Helpman, 1995: 681). If the specific factor is concentrated among few members, the incentive for collective action is strong, which is close to the condition of small size for the formation and efficiency of lobbies. See Olson (1965) for this condition of efficiency through small size.
} 
Lagadec $\bullet$ Are political support-driven policies always bad?

The pioneer analysis of Travis thus corresponds to "endogenous" policies because they are guided by unorganised interest groups (which are therefore not pressure groups). This means that in terms of political support, interest groups should be taken into account by their electoral weight (passive influence) and not by their lobbying, which would necessitate collective action. ${ }^{4}$

\section{From large groups to endogenous economic policies}

The object of this paper is to extend the concept of endogenous economic policy to its widest sense, and not simply limit it to trade protection, to understand whether in this context the traditional negative link between lobbying and welfare would be reversed (see introduction for the sub-optimality of protection)? The definition of an endogenous economic policy is thus close to that of endogenous protection, but it must however be extended in two complementary and related dimensions: (1) by considering that political support in its widest sense is at the base of endogenous policies; and (2) by extending the analysis beyond the perimeter of sector-oriented policies, thus distinguishing global endogenous policies and sector-oriented endogenous policies.

These two dimensions are interrelated in that (unorganised) interest groups are most often large groups (cf. the small size condition for the success of collective action). This feature of size automatically has the effect of increasing the number of agents involved and thus increasing the number of sectors concerned leads to global and not exclusively sector-oriented policies.

In the model of endogenous protection, an economic policy is defined as endogenous as soon as it is implemented according to identified interest groups (interest groups or pressure groups/lobbies) ${ }^{5}$ and not for the consideration of social welfare (classical model of the benevolent dictator). If it is interest groups, it is more in an electoral context (the groups are not taken into consideration for their contribution like in Peltzman (1976), but for their electoral weight during the future election); if it is lobbies, it corresponds to a classical case of lobbying thus including the role of contributions.

The first case corresponds to what we call "global endogenous policies", the second corresponds to "sector-oriented endogenous policies".

\section{Lobbying, interest groups and social welfare}

\section{Classical analysis of the effects on social welfare}

The analysis of the effects of lobbying on the social welfare was initiated by Browning (1974). A source of inefficiency thus appears as lobbying leads to diversion of resources in non-productive activities. ${ }^{6}$ This diversion corresponds to the contributions received by politicians to finance their campaigns, because it is money taken from a productive use. Besides these contributions (standard Peltzmanian case), Rodrik (1986) identified three types of social welfare costs generated by lobbying: (i) the direct cost of lobbying, that is total amount of work diverted from productive activities; (ii) the absolute loss due to excess production

\footnotetext{
${ }^{4}$ Denzau and Munger (1986) also showed that unorganised voters can be indirectly represented in the making of economic policy just because a contrario the lobbies prefer to work with legislator politicians who don't have informed voters opposed to their views in their home districts.

${ }^{5}$ For an historical example of the antagonism between private interests and social welfare in the case of endogenous trade policy, see The Economist (2008). The article describes how the American Free Trade Policy was challenged by the "Tariff Act" of 1930, voted following the initiative of Willis Hawley (Congressman) and Reed Smoot (Senator), in spite of a petition from President Hoover signed by more than a thousand American economists.

${ }^{6}$ These are DUPs popularised by Bhagwati (1980), then Bhagwati and Srinivasan (1980).
} 
from the sector in competition with imports; and (iii) the loss in consumption caused by the increase in the domestic price (Rodrik,1986: 295-296).

Following this, the social cost of lobbying was measured. For example Laband and Sophocleus (1988) showed that profit-seeking drastically reduced the growth of the American GNP by 22.6 percent for the year 1985 (also see Horgos and Zimmermann, 2009a on this point, and Desai and Olofsgard, 2011, for the specific case of developing countries).

Lobbying has been traditionally seen as being used to protect oneself against less expensive imports from the rest of the world. However the protection itself creates a situation of second best. Bhagwati was the first to analyse the problem of second best in a world with lobbying. Bhagwati (1980) considered that trade protection was either exogenous (established without lobbying), or endogenous (established with lobbying) and, in this context, showed that this departure from free trade is not necessarily synonymous with a decline in social welfare. Indeed, the addition of one distortion (lobbying) to another (protection) means that lobbying can have a negative social cost (Bhagwati, 1980: 357). ${ }^{7}$

This paradox was later criticised, particularly by Tullock (1981), who showed that from the time one also considers the matter of customs revenue from the tariff, the paradox is reduced. Finally the paradox disappears if one considers the hypothesis which is widespread in the literature, that the activity of profit-seeking is perfectly competitive. ${ }^{8}$ Such a hypothesis has a corollary of dissipation of the income through the expenses involved in obtaining it; the optimum second best aspect thus disappears. Anam and Katz (1988: 220) showed it starting from monopoly rent, by emphasizing that in this case, the marginal cost of production in the monopolistic sector (including the cost of rent seeking) is reflected in the price.

\section{Unorganised interest groups and social welfare}

Let us now come back to the distinction between "global" and "sector-oriented" policies. The difference is not only semantic (in which case it would suffice to consider "global" and "partial" policies so that the full sense of this distinction can be understood. The distinction can indeed be considered to be deeper. On the one hand, one can consider the analysis of sector-oriented policies which ask the classical questions of aggregated preferences, or of groups of agents who work towards the general interest in their own way, but whose respective interests are in conflict. On the other hand, an analysis of the balance of political power within an economy, with the help of global policies, can be taken into consideration. In the latter case, the interests at stake are not necessarily conflicting and can thus all the more work towards the general interest because taking them into account allows the incumbents to have a function of social welfare (FSW) in keeping with the structuring of society, or at the very least not disconnected from social reality. Furthermore, unorganised groups carry weight by their vote and not by the contributions (cf. Travis, 1968). In this way, they do not divert labour resources like Rodrik, or (especially) contributions like Peltzman. One can therefore consider that the influence of interest groups on economic policy does not include any negative element.

Figure 1 shows that the curve of utility possibilities confronts the two individuals. The figure's shape comes from the fact that the incentives to invest vary according

\footnotetext{
${ }^{7}$ That means that the factors diverted from their productive use have a negative shadow price. This point is explained in detail by Hillman (1989, pp. 53-58) and more especially taken up again by Hillman and Katz (1994: 104).

${ }^{8}$ Cf. Foster (1971: 177), for a definition of competitive rent seeking and cf. Corcoran and Karels (1985: 227), for the general nature of this concept. More precisely, Monissen (1991: 125) studies the rent dissipation conditions.
} 
to redistribution - see Wolfelsperger (1985) for example. Point A corresponds to a Benthamian FSW (addition of utilities), Point $C$ to Rawls' solution, Point D to the egalitarian solution and Point B to any FSW.

Figure 1: Utilities and function of social welfare

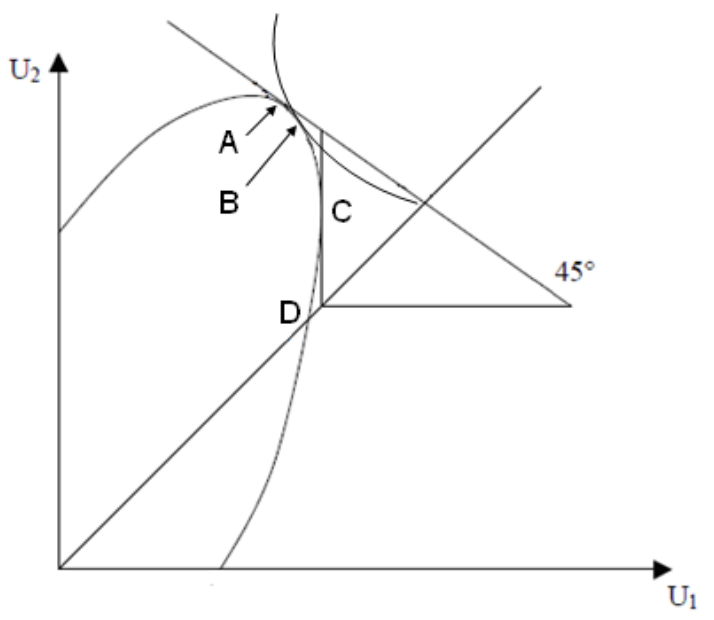

Let us consider Point $B$, which could correspond to taking unorganised interests into account. One is thus in an exogenous context, in which a benevolent dictator imposes his FSW that authoritatively settles questions of intransitivity linked to the collective aggregation of individual preferences. The information here thus goes from interest groups to the incumbent, who best calibrates his FSW. Therefore, although interest groups are passive, they can have a positive impact in terms of social welfare. One thus faces, in some ways, the issue developed in the theories of informative lobbying (Austen-Smith and Wright, 1992; Bennedsen and Feldmann, 2006; or Lagerlöf, 2006). However, whatever the function of social welfare considered, it corresponds to the social preferences of the incumbent and can thus not vary according to the electoral cycles. If it is noted that one group is more assisted just before an election that means that policy is not driven by anF FSW. As soon as the ruler is rational, if his objective function is not an FSW, it can only be a function of political support (possibly camouflaged as an FSW outside the election period: political speech advocating equity, social justice, etc.). So, one is actually in a context of endogenous policy. Private interests, possibly conflicting, thus influence the incumbent who takes them into account according to his function of political support and not according to an FSW.

\section{Empirical relevance}

What do we see in practice? If one looks for an increased activity of the lobbying kind before an election, one will get plenty of examples that simply match the opportunist government model. ${ }^{9}$ The problem is to differentiate systematically what relates to actions in favour of lobbies from what relates to actions in favour of (large) interest groups. There is a way to discriminate between these types of actions, which has been developed in recent works that are mainly empirical and some of which have not been published yet.

Lagona and Padovano (2008) show for the Italian case that parliamentary activity is connected to the political cycle with more laws being voted at the end of the cycle (just before the next election). Brechler and Geršl (2011) analyse the political legislation cycle in the Czech Republic and bring out a two-peak cycle with

${ }^{9}$ Aidt, Veiga and Veiga (2011: 35) have also recently demonstrated that the opportunistic pre-election distortions are connected to the prospect of winning elections: the smaller the win-margin, the higher pre-election distortions. 
legislation activity increasing after the elections followed by a decrease around the middle of electoral cycle. The interpretation of Brechler and Geršl (2011: 20) is first, that incumbents keep their pre-election promises (the first peak after elections), and second, that they maximise political support by voters (the second peak just before next elections). As the analysis focuses on laws connected to transfer payments, that should concern large groups and not specific interests. So, there is a strong presumption that this empirical evidence confirms the relevance of our analysis that large interest groups passively shape political support-driven policies.

Other recent works allow a finer analysis of the differences between favours to the lobbies and favours to the interest groups. Thus Padovano and Petrarca (2012) make an explicit distinction between legislation in the form of laws visible to all agents and decrees visible only to special interest groups. They consider that in order to collect election campaign resources from special interest groups, a legislator generates a pre-electoral cycle of the targeted good by distorting upwards the production of decrees. But, mainly, they show that the legislator generates an electoral cycle of the general public good at the end of the legislature by distorting upwards the production of laws to increase his probability of being reelected (Padovano and Petrarca 2012: 4).

This analysis is tested by Padovano and Gavoille (2013) on French data covering the monthly counts of legislative production from 1959 to 2012 and providing detailed characteristics of the composition of the government as well as personal information about the ministers.

The highest peaks of legislative production (and not decrees) occur towards the end of the legislature. All other things being equal, the legislative production increases by roughly 17 percent in the last year of the legislature, while this increase reaches 13 percent during the last six months of the presidential mandate. As the constitutional reform of 2000 gave the political mandates a time stability by synchronizing the legislative and presidential period, the authors also note that the peak of legislative production is particularly high when the legislature lasts its natural duration length. (p. 8). It means that the 17 percent increase does not come from a "rush to the end" (Padovano and Gavoille, 2013: 8 and 17)

Padovano and Petrarca (2012) and Padovano and Gavoille (2013) allow us to discriminate between actions in favour of the lobbies and actions in favour of unorganised large interest groups. It is then shown that the legislator changes his agenda to favour the large groups at the end of his mandate and thereby distorts his economic policy before the election to make his policy closer to the interest (although not expressed) of large groups.

These empirical analyses demonstrate that, independently of questions of intransitivity, it is certain that the influence of unorganised groups does not contribute to social welfare, even if they do not generate diversion of productive resources (DUPs), since the latter, whatever the form it is given, is not the target of the incumbent (for that we can work on social welfare without being blocked by the Arrow's theorem). In this way, contrary to what it could seem, taking the interests of large groups into account tends to reduce social welfare.

\section{Conclusion}

The activity of interest groups is a source of waste of resources. In exchange for contributions paid (on the whole corresponding to waste), these activities aim at obtaining advantages from public authorities, particularly corresponding to obtaining or keeping market power (a classical case of endogenous protection: lobbies organise themselves to apply pressure with a view to customs tariffs which protect them from international competition). Therefore the economy can no longer be at the optimum and social welfare deteriorates. Apart from a few paradoxical situations, this point is commonly accepted in the literature. In this type of situation, 
Lagadec $\bullet$ Are political support-driven policies always bad?

the efficiency of lobbying is inversely proportional to the size of the group (Olsonian condition): small groups are advantaged (particularly in that their incentives for collective action are stronger, particularly because their per capita gain is higher). This is why large groups are inefficient and do not manage to organise themselves into lobbies. This is especially the case for consumers whose associations have a very weak influence in relation to the number of agents they represent. Nevertheless these large groups can also be taken into account by those in power in a perspective of direct political support,that is through votes (endogenous economic policies in the widest sense influenced by active or passive groups). Moreover it is noted that the attention these groups benefit from depends on the political cycle (Padovano and Petrarca, 2012; Padovano and Gavoille, 2013). As the function of social welfare of the incumbent cannot be subject to these uncertainties (preferences are by definition exogenous), this means that actions in favour of large groups are driven by political support.10

It must be concluded that policies driven by political support, which take the diverse interests of big groups into account, move the economy away from the optimum and reduce social welfare, in much the same way as classical lobbying would do.

\section{References}

Aidt, Toke S., Francisco J. Veiga and Linda G. Veiga (2011) 'Election results and opportunistic policies: A new test of the rational political business cycle model', Public Choice 148: 21-44.

Austen-Smith, David A. and John, R. Wright (1992) 'Competitive Lobbying for a Legislator's Vote', Social Choice and Welfare 9(3):229-257.

Baldwin, Robert E. (1982) 'The Political Economy of Protectionism', in Jagdish N. Bhagwati (ed.), Import Competition and Response, Chicago: University of Chicago Press, pp. 263-292.

Bennedsen, Morten and Sven E. Feldmann (2006) 'Informational lobbying and political contributions', Journal of Public Economics 90(4-5): 631-656.

Bhagwati, Jagdish N. (1980) 'Lobbying and Welfare', Journal of Publicl Economics 14(3): 355-363.

Bhagwati, Jagdish N. and T. N. Srinivasan (1980) 'Revenue Seeking: A Generalization of the Theory of Tariffs', Journal of Political Economy 88(6):10691081.

Brechler, Josef and Adam Geršl (2011) 'Political Legislation Cycle in the Czech Republic', IES Working Paper 21/2011, IES FSV, Charles University.

Browning, Edgard K. (1974) 'On the Welfare Cost of Transfers', Kyklos 27(2): 374377.

Corcoran, Willian. J. and Gordon V. Karels (1985) 'Rent-seeking Behavior in the Long-run', Public Choice 46 (3): 227-246.

Denzau, Arthur T. and Michael C. Munger (1986) 'Legislators and Interest Groups: How Unorganized Interests Get Represented', American Political Science Review 80(1): 89-106.

Farvaque, Étienne and Sonia Paty (2009) Economie de la démocratie, Bruxelles: De Boeck Edition Université.

\footnotetext{
${ }^{10}$ Furthermore, considering that taking large groups into account can be seen as informative lobbying (which increases social welfare) also comes up against the Olsonian condition of efficiency (small size): passive large groups do not appear to be able to efficiently produce information aiming at the promotion of their interests.
} 
Desai, Raj M. and Anders Olofsgard (2011) 'The Costs of Political Influence: FirmLevel Evidence From Developing Countries', Quarterly Journal of Political Science 6(2):137-178.

Foster, Edward (1971) 'The Treatment of Rents in Cost-Benefit Analysis', American Economic Review 71(1): 171-178.

Grossman, Gene M. and Elhanan Helpman (1994) 'Protection for Sale', American Economic Review 84(4): 833-850.

Grossman, Gene M. and Elhanan Helpman (1995) 'Trade Wars and Trade Talks', Journal of Political Economy 103(4): 675-708.

Hillman, Arye L. (1992) 'International Trade Policy: Benevolent Dictators and Optimizing Politicians' Public Choice 74: 1-15.

Hillman, Arye. L. and Eliakim Katz (1994) 'Risk-Averse Rent Seekers and the Social Cost of Monopoly Power' The Economic Journal 84: 104-110.

Hillman, Arye L. (1989) The Political Economy of Protection, London: Harwood Academic Publishers.

Horgos, Daniel and Klaus W. Zimmermann (2009a) 'Interest groups and economic performance: some new evidence', Public Choice 138:301-315.

Horgos, Daniel and Klaus, W. Zimmermann K. W. (2009b) 'It takes two to tango: lobbies and the political business cycle', Working Paper Series, Nr./No. 98, September, Department of Economics; Fächergruppe Volkswirtschaftslehre.

Katz, Eliakim and Jacob Rosenberg (1989) 'Rent-Seeking for Budgetary Allocation: Preliminary Results for 20 Countries' Public Choice 60: 133-144.

Laband, David N. and John P. Sophocleus (1988) 'The Social Cost of RentSeeking: First Estimates' Public Choice 58: 269-275.

Lagerlöf, Johan N. M. (2006) 'A theory of Rent Seeking with Informational Foundations', Discussion Paper Series, CEPR n 5893.

Lagona, Francesco and Fabio Padovano (2008) 'The political legislation cycle', Public Choice 134: 201-229.

Magee, Stephen P. (1997) 'Endogenous Protection: The Empirical Evidence', in Dennis C. Mueller (ed.), Perspectives on Public Choice, Cambridge: Cambridge University Press, pp.526-561.

Mayer, Wolfgang. (1984) 'Endogenous Tariff formation', American Economic Review 74(5): 970-985.

Monissen, Hans G. (1991) 'Rent-Seeking in General Equilibrium: A Didactic Illustration', Public Choice 72: 111-129.

Olson, Mancur (1965) The logic of collective action: public goods and the theory of groups, Cambridge, MA: Harvard University Press.

Padovano, Fabio and Ilaria Petrarca (2012) 'A Theory of Cyclical Production of Laws and Decrees', Working Paper 2012-09, Condorcet Center for Political Economy, University of Rennes 1.

Padovano, Fabio and Nicolas Gavoille (2013) 'The Dual Political Legislation Cycle in France', Working Paper 2013-02, Condorcet Center for Political Economy, University of Rennes 1.

Peirce, Williams S. (1991) 'After 1992: The European Community and the Redistribution of Rents', Kyklos 44(4): 521-536.

Peltzman, Sam (1976) 'Toward a More General Theory of Regulation', The Journal of Law and Economics, 19(2): 211-248. 
Pincus, Jonathan J. (1975) 'Pressure Groups and the Pattern of Tariffs', Journal of Political Economy 83(4): 757-778.

Rodrik, Dani (1986) 'Tariffs, Subsidies, and Welfare with Endogenous Policy', Journal of International Economics 21(3-4): 285-299.

Tollison, Robert D. (1982) 'Rent Seeking: A Survey', Kyklos, 35(4): 575-602.

Travis, William P. (1968) 'The Effective Rate of Protection and the Question of Labor Protection in the United States', Journal of Political Economy 76(3): 443-461.

Tullock, Gordon (1981) 'Lobbying and Welfare: A Comment', Journal of International Economics 16(3): 391-394.

Wellisz, Stanislaw and John Wilson (1986) 'Lobbying and Tariff Formation: A Deadweight Loss Consideration', Journal of International Economics 20(3-4): 367375.

Wolfelsperger A. (1995) Economie Publique, Paris: PUF 